\title{
P04.77. Abstract withdrawn from publication
}

From International Research Congress on Integrative Medicine and Health 2012

Portland, Oregon, USA. 15-18 May 2012 